\title{
The Impact of the Critical Success Factors in the Maturity of E-Government Applications
}

\author{
A Case Study in the "Traffic Department" in Jordan
}

\section{Prof. Dr Mohammed Abed Hussein Altaee}

\author{
Zarqa University / Jordan
}

\begin{abstract}
This paper endeavors to evaluate what key factors are critical to achieving optimal outcomes for egovernment projects, no matter how small or big the project. Prior to the discussion of the critical success factors it is essential to gain some understanding of the concept of e-government, the importance of egovernment application, e-government characteristics In this paper, we have identified several factors that must be considered carefully and understood clearly prior to adopting and implementing a system to support egovernment. However, we believe that the discussion in this paper addresses some generic issues faced by others who are in the process of adopting and/or implementing e-government. Although the paper does not provide an exhaustive list of critical success factors, it hopefully demonstrates the need to address such factors in the development and achievement of coherent and unified e-government capabilities.
\end{abstract}

Keywords: e-government, critical success factors (CSFs), e-government applications maturity

\section{INTRODUCTION}

There have been fundamental changes in the structure of economies in most countries, service sector has become the main economic activity (OECD, 2000a, b), and so, facing of challenges for such an unstable environment is no longer easy. Governments around the world have participated in various mega projects in order to obtain the maximum amount of public services provided electronically during the first of the atheist and the twentieth century decade. E-government project was at the forefront of these projects.

Researches in the past dealt with the issues related to the application of e-government project using "Diffusion Models", For example, (Roger's Diffusion Theory, 1995), Studies have focused on the adoption of information technology in the public sector (Brudney and Selden, 1995; Bugler and Bretschneider, 1993; Brudney and Selden, 1995; Norris and Demeter, 1999; Norris and Campillo, 2000; Moon, 2002; Moon and Norris, 2005; Elliman et al., 2005). All these Studies suggesting among several factors - that the size of management and professionalism are the key determinants of computer technology adoption.

In the same direction, (Rogers, 1995) identify five categories of variables including perceived attributes of innovation ,the type of new service which has been developed by e-government in the framework of innovation decision, communication channels, the nature of the social system and the extent of the promotional efforts made by the change agents.

While (Berry and Berry, 1999) proposes two categories of innovation models and diffusion models, these two models are the diffusion models and internal determinants models. The diffusion models in turn include four sub models including national interaction models (learning models), regional diffusion models, laggard's leadership model (slow) and vertical impact models. The internal determinants models, aims to integrate internal factors, such as motivation, size, resources, etc.

In another study,(Choudrie and Lee, 2004), found that the use of information and communication technology within government departments and agencies will contribute to improving the quality of public services, as well as encouraging bureaucratic organizations to redesign the way in which they provision of services to citizens. However, as (Moon and Norris, 2005) pointed out, there is no only one diffusion model explain better all cases. 
On the other hand, we find that the success of information systems model (DeLone and McLean, 1992) and the acceptance form technology model (Davis, 1989) indicates another way to study the application of e-government through perceived interest and Perceived ease to use the system measuring and which affect the person's attitude towards the use of the system, which in turn affects the individual's behavioral intention to use the system, which, in turn, determines the actual use of the system.

Finally, Success factors identified in the "Davis' model" are the subjective evaluation of the user of the system operations and may not be representative of the acceptance of the model objectively (Carter and Belanger, 2005). From the above, and in spite of the multiplicity of frameworks which expect and excogitate the success of e-government, but the barriers that impeding their application and adoption may exist, for example, the high cost ,Poor security of infrastructure.

\section{STUdy MeThodology}

The methodology of the study is based on five aspects: the problem of the study, its objectives and importance, study model and hypotheses, method of data collection and analysis.

\subsection{The Study Problem}

In the survey, conducted by a researcher (Heeks, 2003) on the success rates and failure in egovernment initiatives in developing countries concluded that $35 \%$ of the total e-government projects fail completely (for example, decision support systems failed in East Africa), however the failure may be partial (Partial failure that has occurred for government administration in the Eastern European countries), as the results indicate that approximately $15 \%$ of all e-government services in these countries have been successful. In the same direction and During the same year, the World Bank (2003) confirmed that the projects based on information and communication technologies in government banking sector faced a high percentage fail horribly, whereas $50 \%$ of these projects have suffered from inconsistencies, and (80\%) of them were need substantial amendments.

On the other hand, many of the studies indicated that despite the fact that most of the e-government initiatives tend to slump in the contracting phase in the framework of the application stages of egovernment, very few of them have succeeded in achieving sophisticated and real effective value added (Layne and Lee, 2001; Holden et al., 2003; Lee et al., 2005; Sarikas and Weerakkody, 2007), and also failed to achieve transparency in electronic services (Weerakkody et al., 2007). Most of these failures have been attributed to the inability of governments around the world to imparted business process recipe, and re-engineering of information systems in e-government model, which was adopted.

The Government of Jordon recognizes the importance of ICT in the public sector. It has therefore prepared this National e-Government Strategy 2013-2018 to provide the required guidance on exploiting the ICT opportunities and addressing challenged for value added public sector services. Despite the existing literature on e-government applications in Jordan, but there is a need for more research to be made. It did not shed enough light on the development of new services in e-government yet,. The bulk of this research has focused on the development of new services in the financial sector, as some recent attempts have focused on the development of services in the hospitality industry, but so far, there is relatively little research on the development of new services in the public sector. Which it requires such studies to fill this gap. This is what stimulated the researcher to conduct this study.

\subsection{The Study Objectives}

This study aims to achieve the following objectives:

a. Identification of e-government, their characteristics and the importance of e-government project application.

b. Clarify the concept of critical success factors (CSFs) and identify the most important (CSFs) related to the application of e-government project.

c. Assess and discuss the contribution of the (CSFs) in the maturity of e-government applications in the "Traffic Department", in Jordan.

d. Make recommendations and proposals necessary to activate the role of the (CSFs) in promoting the success of e-government applications in the "Traffic Department", in Jordan. 


\subsection{The Study Importance}

Governmental institutions seeking to adopt e-government applications, because of the great importance of these applications to the success of these institutions In light of the need the community to government services and methods of delivery of services and technological developments in the information technology areas and systems . This important will increase in the Arab world in general and in Jordan in particular. If we realized the lack of available necessary information on the extent of e-government applications adoption and nature of these applications, types and entities associated with them and the benefits resulting, as well as the costs of them and all of which are sufficient justification for attention and then studied. From here, and in spite of this importance, the interest in this subject in the Arab environment is still below the level of ambition, whether at the level of literature, or at the level of field application, the studies on this subject are very scarce that were not rare, hence the academy importance for this study gliding through the mind of a leading research in this area. While applied important for this study embodied through:

- Provide a general framework illustrating the relationship between Critical Success factors and egovernment applications.

- Alert academics and practitioners interested in the areas of e-government applications, especially public institutions administration to the need to strive towards considering Critical Success factors as a basis for enhancing the success of e-government applications

- Provide an opportunity for researchers to carry out similar studies or efforts to complete this study in the same environment, or in other environments.

\subsection{The Study Model}

This study adopted a model, seen in the figure 1, which indicates the existence of one independent variable (Critical Success factors) which affects the success of e-government applications (dependent variable). The study assumes the existence of a one-way relationship between the variables of the study.

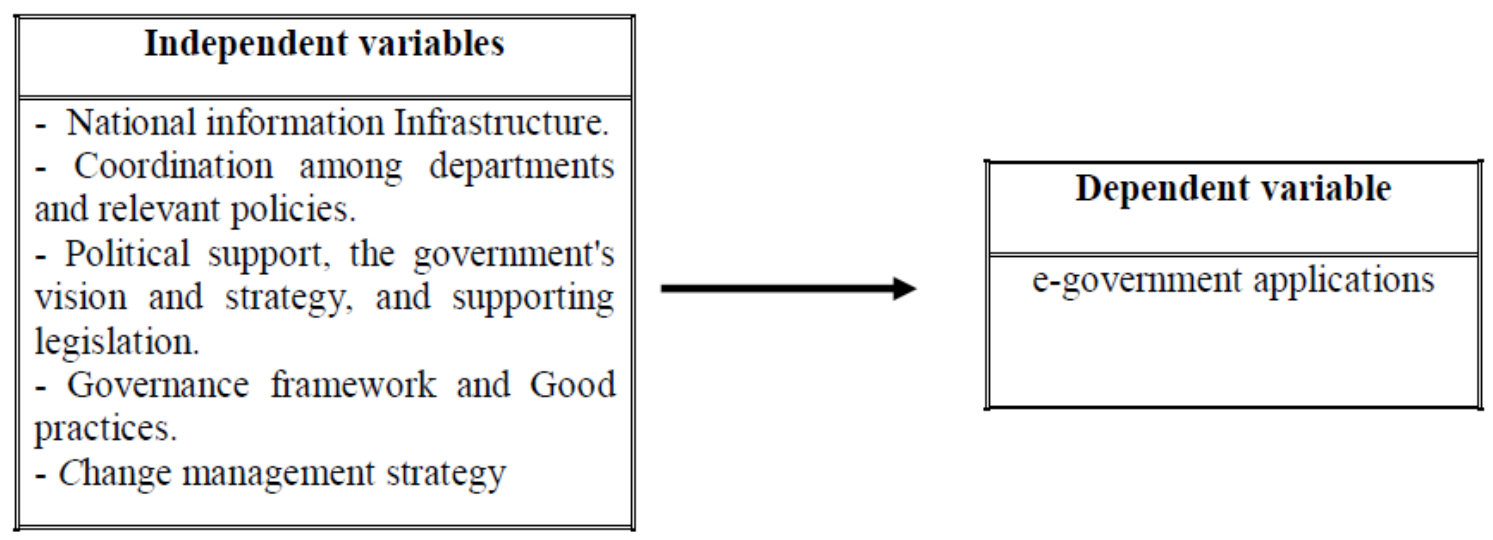

Source: Prepared by the Researcher

Figure1. Study Model

\subsection{The Study Hypothesis}

Based on research objectives and problem and its model, it has been formulating the following hypothesis:

$\mathbf{H}_{0}$ : There is no statistically significant impact for the critical success factors on the success of egovernment applications in the "Traffic Department", in Jordan.

\subsection{Method of Data Collection and Analysis}

As well as with exploratory visits, interview and look at the report issued by the "Traffic Department" in Jordan, the researcher adoption a questionnaire for data collection, which included three parts: the first part about the personal data from respondents, second part was devoted to determining the availability of critical success factors in the "Traffic Department" in Jordan, and the third part devoted to measure the maturity of e-government applications in this department. 
The questionnaire included (44) items, (Appendix 1) shows the distribution of these paragraphs on the variables of the study. Questionnaire was distributed to the study population represented by (Director, Assistant Director, Head of Department), in the "Traffic Department" in Jordan (202) respondents, the number of questionnaires recovered (177) questionnaire, the number of full subjected to analysis (162) questionnaire. The analysis were performed by using (SPSS) program through the following statistical methods :

- Normal distribution, where it is used to see the existence of a normal distribution in the study data as a prerequisite for the use of certain statistical methods, such as multiple regression analysis.

- Cronbach's alpha coefficient: to test the reliability of the data collection tool used to measure the variables of the study .

- Multiple linear regression analysis: To measure the impact of the independent variables on the dependent variable.

\section{Theoretical Part}

\subsection{Critical Success Factors Definition}

Work in the field of E-Government and organizations in general, is based on the principle of recognizing that some aspects are critical to the success of the organization. These aspects are different, and has been classified under the general term is "critical success factors (CSF) ", which is one of the very important issues in the management literature in general.

When searching in the definition of these factors, we find different definitions, but original definition has been providing by (Rockart, 1978), which defined (CSF) as "areas of activity that should be a continuous and careful attention by management through continuous measurement of the current situation of performance in every area, under the provision of the necessary information."

The definition given by (Boynton and Zmud, 1984) consistent with (Rockart) definition, they define critical success factors as "those things that must go well to ensure the success of the organization". (Dickinson et al, 1984) submits more specific definition of the critical success factors "are those events and circumstances, conditions or activities that require special attention from the administration because of its importance."

From our perspective "critical success factors "can be defined as those factors that are related to the goals of the organization, its structure, activities and I, employees that, when available, and observance, certain success for the organization will be achieved.

\subsection{Critical Success Factors Determination}

Consistent with the above definitions, it is important to identify these factors in the early stages of the project in order to maximize its benefits (reaping the benefits of the project), and otherwise ignore, any of these factors with any degree increases the likelihood of project failure.

(Garner, 1986) confirms that the critical success factors in the field of public administration differ from those in the private sector companies, for one reason is that in government agencies, resources are allocated according to political priorities and not according to business needs. Therefore, egovernment project managers need to identify the factors that can help to achieve these priorities from the start. This is done by identifying the factors that have the greatest impact on the project. Researchers have differed in the method of determining these factors; some researchers have suggested adopting "Top-Down "approach to select these factors. (Christine and Rockart, 1981; Freund, 1987).

Some other researchers tried to make these factors more specifically, through the confined between three to six factors, these factors are those that contribute to the success of the project (Daniel, 1961). Others of these researchers preferred to identify these factors through classified into factors linked to internal or external events (Dickinson et al, 1984).

(Oberer, 2002) expands the circle of the critical success factors for e-government through the introduction of technology and citizen factors in the e-government "e-equation ", there should be an adequate use of technology to support e-government. While citizen factor embodies the concept of "demand orientation" of services, this is because the citizen asked the Government to provide quick and simple information, so that citizens dealing directly with government agencies. 
Other researchers add two new factors of critical success factors namely, organizational factors (such as change management processes, coordinate actions related to technology and decision-making); legal factors (rules governing access electronic services and systems relating to security infrastructure). Finally, in their review of the literature relating to the formulation of e-government policy and implementation, the researchers (Altameemet al., 2006) indicated a wide range of factors that lead to success or failure of the e-government, through the provision of multi-factors model influencing the adoption of e-government initiatives decisions.

These factors are technical support, the infrastructure, tools and applications required to enable government agencies to participate in e-government - and regulatory factors adoption, such as the policy and legal issues, quality of service, training, organizational structure, and culture. Accordingly, and for the proper identification of these factors we see the need to be addressed as follows:

\subsubsection{National Information Infrastructure}

Although the use of information and communication technology in government administration is not a magic solution, but it can be seen to be used as a means to expand the scope of limited rationality for decision makers in government organization and provision of basic infrastructure to improve the decision-making process. The researchers assert that the availability of a sound technological infrastructure is one of the keys to the success of the e-government application (Chen et al., 2006; Pons, 2004).

(Chen et al., 2006) adds that "infrastructure development is a necessity before countries can consider any large projects dedicated to the subject of e-government." Undoubtedly, it is without efficient national infrastructure, the citizens' access to any point of contact for e-government will be limited. Thus, the value and usefulness of any initiative for e-government without this infrastructure is questionable. (Nair and Prasad, 2002) indicates that the presence of efficient national infrastructure is a basic necessity for people and businesses to use e-government services. On the other hand, and equally important, the presence of back-office functions performed by the internal systems for government departments' that supports e-government, without proper and sufficient infrastructure back-end, any government department will not be able to provide effective and efficient services to the people through the front end for electronic transactions (such as electronic gate).

The third topic, which has a similar importance in the national information infrastructure is a perfect framework for the governance of information and communication of government technology, this framework includes information and ICT policies, legislation needed to support e-government (such as the passing of electronic transactions and digital signature laws, and to expand the scope of existing laws with relationship evidence, privacy, intellectual property, and freedom of information, and information security in e-government transactions and information stored in electronic form), information and communication principles guidelines for best practices for managing information technology and communications technology project management standards. Moreover, this framework should include both the functions of the back-end and front-end e-Government.

(Sammon \& Adam, 2005) believes that in this day and age where systems integration is the key to achieving the successful implementation of the system, the need is urgent to comprehensive egovernment plan also to provide interoperability between different systems owned and operated by government departments. This need emerged through research conducted by (Lam, 2005) who pointed out that one of the biggest challenges facing the application of e-government is in various egovernment systems merge. This research show the problem lies in the lack of unification in the selection and application of technological software and application development frameworks between government departments.

\subsubsection{Coordination among Departments and Relevant Policies}

Without proper coordination between different departments, there will be a conflict between systems, resulting in a waste of scarce resources already problematic in the integration of information systems and processes (Lam, 2005). The early examples in the literature of the application of e-government, the situation referred to by the (Jorgensen \& Cable, 2002) of the (Corpus Christi Texas) city in the United States in the late (1990), which initiated the steps for creating e-government systems to allow its citizens to find the information And interact with city officials via the Internet, but big problems emerged as a result of the lack of coordination and control of all projects. It should be noted here that 
the necessities of coordination is not limited to only the information of e-government and their own hardware platforms and software systems. It also applies to joint operations and inter-departmental communications and other operations under construction.

Within the same context, (Grant \& Chau, 2005) indicates that it is important to acknowledge that "the integration of applications and services across the government is relatively more complex and problematic than the similar integration in private business." This is because the development of data structures and the unification of tariffs are crucial to the success of information and communication technology initiatives, particularly in joint between the different government department's project initiatives.

The challenge in this area stems not only from obtaining agreement that these structures and those definitions are necessary, but also the involvement of partners are necessary in the development and adoption of common structures and appropriate standards (CTG., 2000). This requires that the relevant authorities make attempts to reduce the relevant data problems through the participation criteria, definitions and metadata with potential partners.

Coordination should include the role of information and communication technology to support and enhance communication and processes between various departments. Bilateral agreements between one government department and the other is not enough, because there is also a need for government policies on a large scale as it comes to communications and processes common interfaces (Combe, 2009).

\subsubsection{Political Support, Government's Vision and Strategy, and Supporting Legislation}

In the context of government and public services, this factor is probably the most important one of all the other critical success factors. Political factors have a significant impact in terms of infrastructure development must be taken into account in the formulation of e-government strategies (Chen et al., 2006; Accenture, 2004).

Although the managers as individuals may not be able to change the rules or institutional official practices. However, if it appears there is a large and diverse coalition, enough to attract the attention of legislators or other policy makers, it can change some of those rules and institutional official practices. In this regard, there are at least two strategies for dealing with institutional and environmental factors: get the executive and legislative support and strategic use of foreign sources (Barki et al, 1993).

Of course, the political support does not necessarily mean carte blanche for those in charge of the application of e-government project, but instead are adopting critical perspective is based on (for example, to exercise caution in evaluating the progress of the project, careful assessment of the milestones and achievements of the e-government initiative, and to ensure the use funding effectively), in contrast, all the necessary facilities to provide the initiative to put into practice (for example, by ensuring that key resources are available and that the supporting legislation in place).

The restrictive laws and regulations that have been applied prior to the adoption of e-government or those that have been adopted in disregard of the relevant e-government technologies affect the success of the enterprise project. One strategy that can be followed to respond to these challenges is to invest in the changes in the regulatory environment that allows or enables the adoption of appropriate technologies (Dawes and Nelson, 1995). Digital signature technology, for example, required in various jurisdictions transactions before being approved for use. The development of policies and standards of appropriate government information technology can also provide the appropriate framework for the success of e-government initiatives (Andersen and Dawes, 1991).

In this regard, various government departments must carry out the development of information technology policies and standards and then make it available through its official Web site. As part of the process of getting this support, the government needs to develop a vision and strategy for a coherent and comprehensive e-government project. (Ke and Wei, 2000) Here refers to the rapid progress of the e-government project in Singapore, mainly due to the integrated strategy for egovernment, which has been adopted by the country's government. Equally important is the subject of effective communication and shared vision and strategy with other stakeholders inside and outside government, to enable them to clear understanding of the government's position and future plans for e-government initiative in the country. 


\subsubsection{Governance Framework and Good Practices}

The development of good governance systems contribute to strengthening the concept of accountability and transparency mechanisms, including administrative law, and standards for best practices, quality assurance, regulatory and supervisory bodies, such as auditors and ombudsmen. In general, the practice of good governance involving the government departments for the individual in the implementation of its programs in ways that are subject to the accountability and reflected the transparency and as consistent with the laws and standards and relevant best practices, along with the implementation of audit programs, quality assurance and record-keeping that support sound management and accountability (Lenk and Traunmu, 2000)

From here the application of good governance practices is very important to the success of any project for electronic government in a country like Jordan, which makes it a priority to be addressed in the early stages of the project issue. The guidelines for good governance and / or practices do not only contribute to the achievement of greater accountability and transparency that will enhance public and stakeholder support for the project, but also contributes to increase the chances of success (King 2000; Lee 1986; World Bank, 2003).

Regarding projects development of information technology and communications systems, such guidelines and practices should be implemented in every stage of the life cycle of the system, but the stage of the purchase of the project is a source of particular concern. In a report issued by the World Bank for the year (2003), he pointed out that public procurement is one of the key areas of corruption and collusion (World Bank report, 2003).

Usually complicity arrangements with the active participation on the part of some government officials occur. Such collusion is part of the procurement process is done through a variety of methods, Including restrictive specifications, and the division of the contract packages, the use of noncompetitive bidding procedures, Limited advertising, shorten the periods of the presentations, and breach of confidentiality during the purchase process.

There is no doubt that such practice, if they occur, they will threaten the success of any project. Bad practices in governance are exacerbated when combined with factors such as excessive reliance on outsourcing partners, non-qualified Staff in IT, the lack of strong experience in project management from the insider staff, a weakness with respect to the basic specifications of the system functions and the needs of users. From the above, the commitment to develop the guidelines and practices of good governance, and make sure to address all the risk factors identified above doubles the chances of success.

\subsubsection{Change Management Strategy}

E-government initiatives have the potential to transform traditional bureaucracy. It involves the inevitable changes in the patterns of communication, work practices and organizational structures, procedures and processes, the adoption and implementation of information and communication technology (Forman, 2002). With the passage of time, and as soon as the departments and offices of government become intertwined in a web of electronic processes and activities, the characteristics of the retina organizations become more widespread than the old forms of bureaucracy (Fountain, 2003).

On the other hand, setting clear and realistic goals is an important factor in the success of egovernment project (Dawes and Pardo, 2002). Also, identify relevant stakeholders and get their participation in the project, especially for end users, it can be an effective strategy to overcome the regulatory and administrative challenges (Barret and Green, 2001). Strategic planning techniques is counted as an umbrella for more specific strategies, such as clear and measurable indicators of achievement (Bajjaly, 1993), Good communication channels (Dawes and Pardo, 2002), And improvements to the processes (Dawes and Nelson, 1995). It is extremely important current institutional care skills and training needs of developers and end-users (Barret and Green, 2001).

Successful e-government projects need to be a balanced mix of technical and organizational skills, and political and experiences among team members (Dawes and Pardo, 2002). On the other hand, the financial resources are not always the most important factor, but necessary. Often, managers need to develop innovative partnerships and financial plans to make e-government initiatives on the ground. (Moon, 2002) concludes that, in order to enhance the effectiveness of e-government applications, public sector organizations need to progress towards a higher level of e-government development, which will require a greater number of highly trained technical staff. 
From the above, in order to anticipate changes that may occur and to ensure the success of egovernment initiatives, the need to develop and implement well thought out change management strategy appear. Education on ICT and its impact must be a part of this strategy.

(Pons, 2004) pointed out that e-government requires technical knowledge and understanding, and lack of education in these technologies is a serious barrier to adoption." Accordingly, the management changes associated with the introduction of e-government project is one of the most challenging in the training program prior to the application of aspects of the project. Hence the need to prepare good capabilities to manage change is an urgent need for the success of the project. Finally, continued to get the feedback from the users, is also an important strategy to maintain the quality of the data (Orr, 1998). Overall, the presence of heterogeneous information and high quality is an important critical success factors (Jiang, et al., 1996).

\section{GoOdness of Measure}

To ensure that the measures developed are reasonably good, the researcher assess the goodness of the measures developed through examining the reliability and validity of the measures, as described below.

\subsection{Face Validity}

The questionnaire was presented to a number of experts (academics in Jordanian universities, and those interested in e-government applications), validate that the instrument measures what its name suggests it measures and agreement on the appropriateness of the paragraphs of the questionnaire.

\subsection{Cronbach'S Alpha Coefficient}

Used to test of inter-item consistency reliability, table (1) shows the results of this test.

Table1. The results of Cronbach's coefficient alpha test

\begin{tabular}{|l|c|c|}
\hline \multicolumn{1}{|c|}{ The study variables } & $\begin{array}{c}\text { Number of items } \\
\text { of each variable }\end{array}$ & $\begin{array}{c}\text { Cronbach's } \\
\text { alpha coefficient }\end{array}$ \\
\hline National information Infrastructure & 7 & 0.74 \\
\hline Coordination among departments and relevant policies & 6 & 0.71 \\
\hline $\begin{array}{l}\text { Political support, the government's vision and strategy, and } \\
\text { supporting legislation }\end{array}$ & 7 & 0.77 \\
\hline Governance framework and Good practices & 6 & 0.69 \\
\hline Change management strategy & 8 & 0.82 \\
\hline Critical success factors( total) & 34 & 0.88 \\
\hline e-government applications success & 10 & 0.81 \\
\hline All variables & $\mathbf{4 4}$ & $\mathbf{0 . 9 1}$ \\
\hline
\end{tabular}

From Table 1 above notes that Cronbach's alpha coefficient per search variables more than $(60 \%)$ and these values are acceptable for the purposes of research data analysis, the alpha coefficient of all variables was $(0.91)$.

\subsection{Hypothesis Testing}

The results of multiple regression analysis Table (2) indicates a positive and significant effect to the critical success factors in the success of e-government applications, where the value of $(\mathrm{F}=15.333)$ at the level of (Sig. $=0.000)$, which means rejecting the of null hypothesis and acceptance alternative hypothesis (There is a statistically significant effect for the critical success factors (combined) on the success of e-government applications). The results also indicate that the critical success factors explain $(27 \%)$ of the variation in the success of e-government applications, and that all the five Critical Success factors affecting the success of e-government applications, the most influential success factor was (political support, the government's vision and strategy, and supporting legislation), according to Beta coefficient values.

Table2. The results of multiple regression analysis

\begin{tabular}{|c|c|c|c|c|c|}
\hline Multiple R & R Square & $\begin{array}{l}\text { Adjusted } \\
\text { R Square }\end{array}$ & F Value & Sig. F & $\begin{array}{c}\text { Durbin- } \\
\text { Watson }\end{array}$ \\
\hline $\mathbf{0 . 5 3 4}$ & $\mathbf{0 . 2 8 5}$ & $\mathbf{0 . 2 6 7}$ & $\mathbf{1 5 . 3 3 3}$ & $\mathbf{0 . 0 0 0}$ & $\mathbf{2 . 0 8 7}$ \\
\hline Test of Normality: Shapiro- Wilk & \multicolumn{2}{|c|}{$\mathbf{0 . 0 5 5}$} & Result: Normal \\
\hline \multicolumn{2}{|c|}{ Independent Variables } & $\begin{array}{c}\text { Standardized } \\
\text { Coefficients (Beta) }\end{array}$ & T Value & Sig. T \\
\hline
\end{tabular}


The Impact of the Critical Success Factors in the Maturity of E-Government Applications

\begin{tabular}{|l|c|c|c|}
\hline \hline National information Infrastructure & $\mathbf{0 . 2 3 6}$ & $\mathbf{2 . 9 6 5}$ & $\mathbf{0 . 0 0 3}$ \\
\hline $\begin{array}{l}\text { Coordination among departments and } \\
\text { relevant policies }\end{array}$ & $\mathbf{0 . 2 5 8}$ & $\mathbf{4 . 3 2 1}$ & $\mathbf{0 . 0 0 0}$ \\
\hline $\begin{array}{l}\text { Political support, the government's vision } \\
\text { and strategy, and supporting legislation }\end{array}$ & $\mathbf{0 . 3 7 1}$ & $\mathbf{5 . 5 2 2}$ & $\mathbf{0 . 0 0 0}$ \\
\hline $\begin{array}{l}\text { Governance framework and Good } \\
\text { practices }\end{array}$ & $\mathbf{0 . 2 9 7}$ & $\mathbf{3 . 5 9 8}$ & $\mathbf{0 . 0 0 0}$ \\
\hline Change management strategy & $\mathbf{0 . 2 6 8}$ & $\mathbf{3 . 4 7 0}$ & $\mathbf{0 . 0 0 1}$ \\
\hline
\end{tabular}

\section{CONCLUSIONS AND RECOMMENDATIONS}

\subsection{Conclusions}

Pursuit of success of the e-government project requires taking into account all the factors that affect it. These factors, according to experts, must be observed at the beginning of the project. This is because the focus on these factors when initiating the design of e-government will lead to more successful projects project. This means that the Traffic Department" in Jordan must focus on the full picture of egovernment critical success factors, not just one or two aspects of e-government, particularly the deployment of e-government information technology perspective to the critical success factors, which leads to ignore many other unique e-government factors.

On the other hand, exclusive in e-government applications in the "Traffic Department" in Jordan on the needs and requirements of the front offices of its departments represents only the first phase of the e-governance project. From here, the transformation of the application to the needs of the front office to be extended to the needs and requirements of back-office means access to what is referred to in the literature "technological government".

Finally, the Traffic Department" in Jordan is seeking to apply the principles of quality management in the provision of electronic public services and reduce the multiple problems associated with the quality of public e-services, in the context of taking into account the remarkable transformation in the provision of government services from traditional channels to the Internet to enhance the quality of these services. This means that knowledge of critical success factors will contribute to the development of new services in e-government and then make the desired progress.

\subsection{Recommendations}

Before taking further investments in individual e-government projects, particularly in the context of the back-end / back-office infrastructure within the government, there is a need to provide a sound framework for an integrated government approach to the design and implementation of information systems. This framework, If not develop and implement before the lapse of individual government departments on to develop their own internal systems, these individual projects will face higher challenges and risks. The existence of design standards, and guidelines for the management of information and communication technology projects, data standards, metadata standards, structural systems and security protocols standards, will enable individual government departments to work within an application suitable environment, and enhance the ability to share and exchange data and information between all government departments also provide the basis to make government information available via the Internet. Here it is advised to take advantage of the experiences of other countries and see the policies developed by other government departments all over the world in the application of e-government and the development of e-government systems.

In a country like Jordan, where the features and the foundations of democracy did not settle down and reach the level of maturity and relations between the legislative and executive bodies, lacking the more balance, there is an urgent need to provide political support and cooperation between the government and the Legislative Council to ensure the success of e-government project.

\section{ACKNOWLEDGEMENT}

This article supported by Zarqa University 


\section{REFERENCES}

[1] Accenture (2004) "The Government Executive Series e-Government Leadership: High Performance, Maximum Value", Retrieved July 14, 2006 from http://www.accenture.com/ Global/Research_and_Insights/By_Industry/Government/HighValue.htm

[2] Altameem, T., Zairi, M. and Alshawi, S. (2006), "Critical success factors of e-government: a proposed model for e-government implementation", IEEE, available at: http:// ieeexplore.ieee. org/ stamp/stamp.jsp?arnumber $1 / 404085489$

[3] Andersen, D. F., \& Dawes, S. S. (1991). Government information management. A primer and casebook. Englewood Cliffs, NJ7 Prentice Hall.

[4] Bajjaly, S. T. (1999). Managing emerging information systems in the public sector. Public Performance and Management Review, 23(1).

[5] Barki, H., Rivard, S., \& Talbot, J. (1993). Toward an assessment of software development risk. Journal of Management Information Systems, 10.

[6] Barret, K., \& Green, R. (2001). Powering up. How public managers can take control of information technology. Washington, DC7 CQ Press.

[7] Berry, F.S. and Berry, W. (1999), "Innovation and diffusion models in policy research", in Sabatier, P. (Ed.), Theories of the Policy Process, West view Press, Boulder, CO.

[8] Boynton A. and Zmud R. (1984). "An Assessment of Critical success factors Loan Management Review", 25(4).

[9] Brudney, J. and Selden, S. (1995), "The adoption of innovation by smaller local governments: the case of computer technology", American Review of Public Administration, Vol. 25.

[10] Bugler, D. and Bretschneider, S. (1993), "Technology push or program pull: interest in new information technologies within public organizations", in Bozeman, B. (Ed.), Public Management: The State of the Art, Jossey-Bass, San Francisco, CA.

[11] Carter, L. and Belanger, F. (2005), "The utilization of e-government services: citizen trust, innovation and acceptance factors", Information Systems Journal, Vol. 15.

[12] Chen, Y.N., Chen, H.M., Huang, W., and Ching, R.K.H. (2006). E-Government strategies in developed and developing countries: An implementation framework and case study. Journal of Global Information Management, vol. 14(1).

[13] Choudrie, J. and Lee, H. (2004), "Broadband development in South Korea: institutional and cultural factor", European Journal of Information Systems, 13(2).

[14] Christine, B. and Rockart, J.(1981). "A Primer on Critical success factors," Center for Information Systems Research Working Paper No. 69.

[15] Combe, C. (2009), "Observations on the UK transformational government strategy relative to citizen data sharing and privacy", Transforming Government: People, Process and Policy, Vol. 3 No. 4.

[16] CTG. (2000). The insider's guide to using information in government. Albany, NY7 Center for Technology in Government http://demo.ctg.albany.edu/static/usinginfo

[17] Daniels, M. (2002), E-government Strategy: Simplified Delivery of Services to Citizens, Office of Management and Budget, Washington, DC.

[18] Davis, F. D. (1989). Perceived usefulness, perceived ease of use and user acceptance of information technology. MIS Quarterly, 13.

[19] Dawes, S. S., \& Nelson, M. R. (1995). Pool the risks, share the benefits: Partnerships in IT innovation. In J. Keyes (Ed.), Technology Trendlines. Technology Success Stories from Today's Visionaries. New York7 Van Nostrand Reinhold;

[20] Dawes, S. S., \& Pardo, T. (2002). Building collaborative digital government systems. In W. J. McIver \& A. K. Elmagarmid (Eds.). Advances in Digital Government. Technology, Human Factors, and Policy. Norwell, MA: Kluwer Academic Publishers.

[21] DeLone, W.H. and McLean, E.R. (1992), "Information systems success: the quest for the dependent variable", Information Systems Research, 3(1).

[22] Dickinson, R.., Ferguson, C. and Sircar, S. (1984). " Critical success factors and Small Business", American Journal of Small Business, 8(3): 49-57, 
[23] Elliman, T., Irani, Z., Love, P.E.D., Jones, S. and Themistocleous, M. (2005), "Evaluating egovernment: learning from the experiences of two UK local authorities", Information Systems Journal, Vol. 15.

[24] Forman, M. (2002). E-Government Strategy: Simplified Delivery of Services to Citizens. Executive Office of the President, Office of Management and Budget, Washington D.C..

[25] Fountain, J. E. (2001). Building the Virtual State. Information Technology and Institutional Change. Washington, DC: Brookings Institution Press.

[26] Freund, P. (1987). "The Hows and Whys of Critical success factors," The CPA Journal, Vol. LVII, No. 5, May.

[27] Garner, L. (1986). "Critical success factors in Social Services Management," New England Journal of Human Services, Vol. 6, No. 1.

[28] Grant, G. and Chau, D. (2005), "Developing a generic framework for e-government", Journal of Global Information Management, Vol. 13 No. 1.

[29] Heeks, R. (2003), "Most e-government-for-development projects fail: how can risks be reduced?", iGovernment Working Paper Series, IDPM, University of Manchester, Manchester.

[30] Holden, S.H., Norris, D.F. and Fletcher, P.D. (2003), "Electronic government at the local level: progress to date and future issues", Public Performance \& Management Review, 26(4)..

[31] Jiang, J., Klein G., \& Balloun, J. (1996). Ranking of system implementation success factors. Project Management Journal, 27.

[32] Jorgensen, D.J. and Cable, S. (2002). Facing the challenges of E-Government: A case study of the city of Corpus Christi, Texas. SAM Advanced Management Journal, vol. 67(3).

[33] Ke, W. and Wei, K.K. (2004). Successful E-Government in Singapore. Communications of the ACM, 47(6).

[34] King, D.Y. (2000). Corruption in Indonesia: A curable cancer? Journal of International Affairs, 53(2).

[35] Lam, W. (2005). Barriers to E-Government integration. The Journal of Enterprise Information Management, 18(5).

[36] Layne, K. and Lee, J. (2001), "Developing fully functional e-government: a four-stage model", Government Information Quarterly, 18(2).

[37] Lee, R.P.L. (1986). Bureaucratic corruption in Asia: The problem of Incongruence between legal norms and folk norms. In L.V. Carino (ed.), Bureaucratic Corruption in Asia, JMC Press, Quezon.

[38] Lee, S.M., Tan, X. and Trimi, S. (2005), "Current practices of leading e-government countries", Communications of the ACM, 48(10).

[39] Lenk, K. and Traunmu“ 1ler, R. (2000), “A framework for electronic government”, Database and Expert Systems Applications, Vol. 10.

[40] Moon, M.J. (2002), "The evolution of e-government among municipalities: rhetoric or reality", Public Administration Review, 62(4).

[41] Moon, M.J. and Norris, D.F. (2005), "Does managerial orientation matter? The adoption of reinventing government and e-government at the municipal level", Information Systems Journal, Vol. 15.

[42] Nair, K. and Prasad, P. (2002). Development through Information Technology in developing countries: Experiences from an Indian state. The Electronic Journal on Information Systems in Developing Countries, 8(2).

[43] Norris, D.F. and Campillo, D. (2000), "Factors Affecting Innovation Adoption by City Governments: The Case of Leading Edge Information Technologies", Maryland Institute for Policy Analysis and Research, University of Maryland, Baltimore, MD.

[44] Norris, D.F. and Demeter, L.A. (1999), "Computing in American city governments", The 1999 Municipal Yearbook, International City/County Management Association, Washington, DC.

[45] OECD (2000a), Annual Report 2000, Organisation for Economic Cooperation and Development, available at: www.oecd.org/dataoecd/30/59/1842666.pdf (accessed 3 February 2005).

[46] OECD (2000b), "Science, technology and industry", The Service Economy Business and Industry Policy Forum Series, Organisation for Economic Cooperation and Development, Paris. 
[47] Orr, K. (1998). "Data quality and systems theory". Communications of the ACM, 41(2).

[48] Pons, A. (2004). E-Government for Arab countries. Journal of Global Information Management, $7(1)$.

[49] Rockart, J. (1978). "A New Approach To Defining The Chief Executive's Information Needs", Center for Information Systems Research, Sloan School of Management Massachusetts Institute of Technology, Cambridge.

[50] Rogers, E. (1995), Diffusion of Innovations, 4th ed., The Free Press, New York, NY.

[51] Sammon, D. and Adam, F. (2005). "Towards a model of organisational prerequisites for enterprise-wide systems integration: Examining ERP and data warehousing". Journal of Enterprise Information Management, 18(4).

[52] Sarikas, O.D. and Weerakkody, V. (2007), "Realising integrated e-government services: a UK local government perspective", Transforming Government: People, Process and Policy, 1(2).

[53] Weerakkody, V., Janssen, M. and Hjort-Madsen, K. (2007), "Realising integrated e-government services: a European perspective", Journal of Cases in Electronic Commerce, 3(2)

[54] World Bank (2003), “Task managers' ICT toolkit: good practice for planning, delivering and sustaining ICT products", Report No. 25919-A/B, Global ICT Department, Washington, DC. 